International Journal of English Literature and Social Sciences
Vol-6, Issue-4; Jul-Aug, 2021
Journal Home Page Available: $\underline{\text { https://ijels.com/ }}$
Journal DOI: $10.22161 /$ ijels

\title{
Who can Translate Dalit Discourses?
}

Peer-Reviewed Journal

\author{
Vandhana Nair N
}

PhD scholar, Srinivas University, Mangalore, India

Received: 03 Jul 2021; Received in revised form: 15 Jul 2021; Accepted: 25 Jul 2021; Available online: 06 Aug 2021 (C2021 The Author(s). Published by Infogain Publication. This is an open access article under the CC BY license (https://creativecommons.org/licenses/by/4.0/).

\begin{abstract}
The authenticity of the silenced voices arises the thought whether dalit themselves should be the authentic authors of Dalit Literature or anyone else could be. Language canon literally buried the ferries and prosperity of the subaltern literature. A shift in politics would be customary when designed and re encoded for different audiences by a differet writer. Literature born from a dalit writer will be twice as powerful as an inexperienced resulting in an impossibility of any non dalit to express the same in a different manner with equivalent words and expressions, it is challenging that a translator carries a text beyond barriers or borders. The challenges of preserving myths, rituals, social customs and belief systems melded with the culture and history often displaced the romantic flights of imagination of literature. The purpose of raising awareness in the translator to address and explore the readers of the target language; the method of dealing with the aspects of the literature would be influenced. This emerging discourse is elevated to a culturally and politically modified form of action that seeks to redefine existing tradition and creating new ones. The resistance of the years of cultural and linguistic colonization with literature and its translation would be of great challenge.
\end{abstract}

Keywords - authenticity, Dalit writing, marginalized, segregated, translation of marginalized literature, translation politics.

Translation of the marginalized discourses is the current area of interest in translation studies. Translation as a process cannot mean merely the transfer of language, but it must be a political act often relied on social, cultural and economic motives. Dalit writing, a branch of literature, has gained wide reception in the recent past, is one of the most translated discourses in India. These writings claims identity and existence of the marginalized class, has to recreate the original discourses of the text through translation. There arise fundamental questions, who can translate a text of a marginalized section? This paper primarily attempts to address this question with the help of an acclaimed essay "Thoughts on African Novel" by Chinua Achebe.

Language is the media of communication, which promotes the development of their talents, skills, creativity, innovation and novelty. Language is a fundamental site of struggle in subaltern discourses resisting translation, because colonization begins in language. 'Can subaltern speak?' by Gayathri Spivak referring to the colonizercolonized outline, has been quoted by Dalit literary critics all over as a caste -based socio-cultural and economic structure of the Indian society. The early Indian aesthetics marked the dalits as untouchables even from literatures and languages. The only action they could perform is the selfless service for the upper caste. The tradition, culture, and ethnicities of the upper caste over the dalits treated as subaltern and with the perception of isolation. In milieu of the subalternity one has to recognize the deliverance of the subverted group, whose silenced voices have brought an authentic portrayal of their pain and suffering, that created a self-identity of their own. Dalit literature represents this century old historic suppression, segregated, debarred and marginalized. In this context the thought arises who writes the authentic literature of Dalit or whether a Dalit themselves should write their story or anyone else can write for them? 
When the matter of dalit discourses turn up -there itself compartmentalization happens in terms of canon gaucho languages in such discusses the delay. Many were rejected and the literally cambridge exit in such a manner that it can only be stories and they can never be ferries, or happiness, prosperity and power can never elevate them. So they eat whenever rise out of stigmata that they make them back last drop to levels saints row, reservations overseas, recognize cold and antonyms at all those times and resumes to look at them has never changed ; find them as an old and under privilege have never changed; language is and reminding that everybody is frame to freeze the litter suppressed. Regulates this message as so it does this causes our experiences of operation and recognization as a cannon and culture falls to take that there is a question to be verified.

Dalit literature is a literature of and about marginalized discourses analyzed and explored specific challenges that involved responses and reactions in the life of the suppressed. When these texts encoded, designed and extended in a vernacular language, re -encoded for different audience by a different writer who is not directly involved or familiar with would follow a different politics .Translation can be best expressed as a canon or tradition to be simply described as a means of sharing knowledge for a different audience. But in the context of Dalit literature translation of a Dalit discourse can never be sharing experience in a different language or for a different audience that text may confront the whole histories of oppression and marginalization, the injustice inflicted on the lower caste by the upper. Obviously the text from the marginalized would embody an act of resistance and expression of anger.

Certainly translation of a Dalit discourse from the vernacular language would surely raise the heights of these literatures in the rest of the world.In other words the language politics can alone can't hold the reception in mainstream but the question arises with the untranslatability of the experiences of operation that a Dalit has and the non Dalit don't. The reception filtered through encoding and re-encoding is in fact is danger. Translation can essentially be described as to communicate the meaning of one language into another without disturbing the originally felt emotions. Translation is always interwoven with native culture and therefore culture specific jargons which can speak beyond words will be evident. Thus can't find a substitute in another language, this challenge will be more in the case of a marginalized literature since the discourse would be literally in terms of language as well as in terms of culture distinct and distant to a non-Dalit.The frustrating and traumatic experience is the central theme of almost every
Dalit discourses which is totally strange to a non Dalit.The question of Identity and the self will be in question during translation .The culture and literature of society of caste society never accommodated Dalit's, there was no space for the less and so the canon was imposed on them. The recognition of the lower caste people is always rejected and their dreams and aspirations neglected. Literature born originally from a Dalit writer will be twice as powerful as an experienced resulting in an impossibility of any non Dalit to express the same in a different language with equal words and expressions, it is challenging that a translator carries a text beyond barriers or borders.

In conventional literature, there is no place for the Dalit's moreover they are portrayed by the upper caste writers as bizarre people. As a subaltern discourse, Dalit literature recounts the existing social conditions of the Dalits and creates in them the literary practice. Literature on adivasis, shaped by perspectives of authors who may or may not have interacted or studied the tribal and their lives, could be romantic flights of the imagination or grim portraits about trials and tribulations of the tribal. Displeased by these fanciful and misrepresentation of his community, Narayan, a member of the Malaarayar tribal community in Kerala, took up the pen to the first authentic novel by an adivasi in south India.

At a time when tribals all over India were fighting a battle to preserve their land and cultural identity Kocharethi reminds us, yet again, how these children of the land were marginalized by the state, the establishment and organized religion. "The misrepresentations were marginalizing a marginalized community. I wondered what I could write about and that is when I decided to stick to what I knew best. So I chose to describe my life, upbringing and culture, says Narayanan" (the hindu, 2011). The novel melding history with culture, the work portrays their many struggles: from possession and dispossession of land to the challenges of preserving myths, rituals, social customs, and belief systems.

Literature has a social and political importance. It provides necessarily a critical perspective on everyday experience and enables us to encounter same threats that they face in their daily life. The very term Dalit along with literature cause a consciousness embedded to contribute to the stand apartness of the literature. When Dalit literature recommend literature opposing feudalism capitalism and caste preferences it also advocates equality independence and rights. The agony that the Dalits suffered for thousands of years manifests itself clearly in their work. The purpose of raising awareness in the translator to address and explore the readers of the target language, the method of dealing with the aspects of the literature would 
be influenced. The demonstration of the essential role of translated text in the global world really is in question in this case. Translation of a text into a world language that makes a translator conscious of his or her language that as a universally accepted slang of language, which ultimately reduces the impact of the Dalit literary text.

Translation is an emerging discourse of today and it has a universal acclaimed recognition.Thus translation is elevated to a culturally and politically modified form of action that seeks to redefine existing tradition and creating new ones. There is certainly a process of cultural and linguistic colonization and certainly when it relates to the literature that has been for years resisting against these colonization's would really be of a great challenge.

\section{REFERENCES}

[1] (2011, april 3). Retrieved from the hindu: http://www.thehindu.com/features/metroplus/article177299 8

[2] Achebe, c. (n.d.). thoughts on african novel.

[3] M Dasan, v. p. (2012). the oxford india anthology of malayalam dalit writing. delhi: oxford.

[4] Narayanan. (2011). the araya woman. (c. thankamma, Trans.) new delhi: oxford university press.

[5] Soumya nair, a. k. (2017). languages and cultural discourse of indian dalit literature from a subalternist perspective. international journal of management and applied science, vol3. 